\title{
Um novo ambiente para as produções narrativas: a influência dos sujeitos em (re)ação
}

\section{Elizabeth Goncalves ${ }^{1}$ \\ Marli Santos ${ }^{2}$}

Recibido: 2015-08-30

Enviado a pares: 2015-08-30
Aprobado por pares: 2015-09-27

Aceptado: 2015-10-07

DOI: 10.5294/pacla.2016.19.2.5

Para citar este artículo / To reference this article / Para citar este artigo

Goncalves, E. \& Santos, M. (Junio de 2016). Um novo ambiente para as produções narrativas: a influência dos sujeitos em (re)ação. Palabra Clave, 19(2), 450-472. DOI: 10.5294/ pacla.2016.19.2.5

\section{Resumo}

As características interacionais da sociedade contemporânea, determinadas pela evolução tecnológica aplicada aos processos de comunicação, marcam uma ênfase nos sujeitos e nos seus fazeres, e substitui a centralidade das estruturas sociais. Temos o desenho de um novo cenário das relações dos sujeitos com os meios de comunicação tradicionais e o investimento em novos meios que venham a suprir as lacunas deixadas por aqueles. $O$ papel do receptor, agora elevado à categoria de participante, de "ator", de produtor, de "prossumidor", constitui o foco deste texto. Entendemos que nem sempre os níveis de interação e os impactos causados nos sujeitos da ação (ou sujeitos em (re)ação) pelas tecnologias promovem a comunicação efetiva, ou seja, o compartilhamento. Em vez de agir apenas reagem, na medida em que as relações sociais estão imersas em uma realidade complexa, com di-

\footnotetext{
Universidade Metodista de Sao Paulo. Brasil. bethmgoncalves@terra.com.br

Universidade Metodista de Sao Paulo. Brasil.marli.santos@metodista.br
} 
versas fontes e plataformas. As interações por meio de ações e/ou reações a partir de demandas resultam em novas práticas comunicacionais e novos formatos midiáticos, encontrados tanto no jornalismo quanto na publicidade, mas também nos textos das organizações em geral em contato com seus variados públicos. $\mathrm{O}$ artigo está pautado por uma revisão de literatura sobre a temática e uma exemplificação de casos emblemáticos dará origem à reflexão proposta.

\section{Palavras-chave}

Comunicação; interação; sujeitos; meios de comunicação; internet (Fonte: Tesauro da Unesco). 


\section{Un nuevo entorno de producción narrativa: la influencia del sujeto en (re)acción}

\section{Resumen}

Las características interaccionales de la sociedad contemporánea, determinadas por la evolución tecnológica aplicada a los procesos de comunicación, marcan un énfasis en los sujetos y en sus quehaceres, y reemplazan la centralidad de las estructuras sociales. Tenemos un diseño de un nuevo escenario de las relaciones de los sujetos con los medios de comunicación tradicionales y la inversión en nuevos medios que llenan los vacíos dejados por aquellos. El rol del receptor, ahora puesto en la categoría de participante, de "actor", de productor, de "prosumidor", constituye el foco del texto. Entendemos que no siempre los niveles de interacción y los impactos causados en los sujetos de la acción (sujetos en [re]acción) por las tecnologías promueven la comunicación efectiva, es decir, la compartibilidad. En vez de actuar, solo reaccionan, a medida que las relaciones sociales están inmersas en una realidad compleja, con diversas fuentes y plataformas. Las interacciones por medio de acciones o reacciones a partir de demandas resultan en nuevas prácticas comunicacionales y nuevos formatos mediáticos, encontrados tanto en el periodismo como en la publicidad, pero también en los textos de las organizaciones en general en contacto con sus variados públicos. El artículo está pautado por una revisión de literatura acerca de la temática, y una ejemplificación de casos emblemáticos dará origen a la reflexión planteada.

\section{Palabras clave}

Comunicación; interacción; sujetos; medios de comunicación; Internet (Fuente: Tesauro de la Unesco). 


\section{A New Environment for Narrative Productions: The Influence of the Subjects in (Re)action}

\section{Abstract}

An interactional feature of contemporary society, determined by the technological evolution applied to communication processes, makes an emphasis on the subjects and their tasks, and replaces the centrality of social structures. We have a design of a new stage of relations of subjects with traditional media and new media investment to fill the gaps left by those. The role of the receptor, now put in the category of participant of "actor", producer of "prosumer" is the focus of the text. We understand that not always the levels of interaction and the impacts on the subject of the action (subject to (re)action) by promoting effective communication technologies, i.e. shareability. Rather than act, only react, as social relations are embedded in a complex reality, with different sources and platforms. Interactions through actions and / or reactions to result in demands from new communication practices and new media formats, found in both journalism and advertising, but also in the texts of the organizations in general in touch with various public. The article is scheduled for a review of literature on the subject, and an example of emblematic cases that give rise to reflection raised.

\section{Keywords}

Communication; interaction; subjects; media; Internet (Source: Unesco Thesaurus). 


\section{Introdução}

Um galo sozinho não tece uma manhã: ele precisará sempre de outros galos. De um que apanhe esse grito que ele deu e o lance a outro; de um outro galo que apanhe o grito de um galo antes e o lance a outro; e de outros galos que com muitos outros galos se cruzem os fios de sol de seus gritos de galo, para que a manhã, desde uma teia tênue, se vá tecendo, entre todos os galos. (João Cabral de Melo Neto - Tecendo a manhã)

O poema de João Cabral de Melo Neto nos remete ao conceito de interação ${ }^{3}$ como a base da experiência humana. Tudo o que existe no universo depende fundamentalmente das relações que se estabelecem. Assim, o tecido que envolve o indivíduo e o insere no mundo é a narrativa. Todo discurso é construído a partir de uma ação conjunta e não de uma linearidade que pressupõe a ação de um sobre o outro passivo, pois cada sujeito imprime à relação comunicativa aspectos que permitem o seu reconhecimento e exigem que as ideias sejam tratadas de uma forma e não de outra.

Nesse sentido, a nova ecologia midiática valoriza o sujeito nas relações sociais e emerge como uma necessidade na sociedade contemporânea. As estruturas rígidas que determinavam os comportamentos e submetiam os sujeitos passam a ser determinadas por suas ações e reações. A interatividade promovida pelas novas tecnologias digitais faz emergir o indivíduo como sujeito, de fato, no processo. Assim, surgem novas práticas comunicacionais em diversas esferas, desde as relações interpessoais, no contexto familiar ou escolar, por exemplo, até nas relações mais complexas das comunicações midiáticas, institucionais e mercadológicas.

É no cenário das novas práticas comunicacionais que destacamos a construção de discursos sociais que dão ênfase ao sujeito, à sua participação

3 Interação, de acordo com Jensen, diz respeito à "ação de dois ou mais indivíduos em interdependência mútua" (Jensen, 1998, p. 201, tradução nossa), ou seja, uma situação de comunicação interpessoal. 
e colaboração na produção de outras narrativas —a princípio, mais polifônicas-, ainda que as ações ou as práticas nem sempre sejam coerentes com tais discursos. A cultura que privilegia o contato e valoriza a interação em diferentes níveis nem sempre promove a comunicação efetiva, ou seja, o compartilhamento. Em vez de agir apenas reagem, na medida em que as relações sociais estão imersas em uma realidade complexa, com diversas fontes e plataformas, em um oceano de informações, cliques e deslizamentos táteis em dispositivos móveis, na velocidade frenética das tecnologias digitais. A disfunção narcotizante, apontada por Lazarsfeld e Merton (citado por Wolf, 1999) — ao referir-se ao excesso de informação gerado pelos meios de comunicação de massa e à consequente paralização do sujeito, que apenas consome a informação—, foi potencializada pela internet e as novas tecnologias com a importante diferença que agora todos os incluídos digitais são potencialmente emissores e disseminadores de informação.

Nesse contexto, o presente texto propõe uma reflexão sobre as características mais importantes das relações na nova ecologia midiática e explora os aspectos por vezes contraditórios entre as novas práticas comunicacionais e as narrativas presentes nas comunicações midiáticas e organizacionais. Para tanto, recorreu-se à pesquisa bibliográfica, ilustrada com exemplos sobre o tema.

\section{Narrativa: base do processo comunicacional}

Contar histórias está na essência do homem, pois a narratividade é característica intrínseca da linguagem humana, que organiza o pensamento na ordem do tempo dos acontecimentos e atribui sentido aos fatos ao relacioná-los com a experiência. A própria existência do homem é uma grande narrativa, construída a partir de tantas outras narrativas paralelas, complementares ou contrastantes, mas em constante diálogo.

A narrativa traduz o conhecimento objetivo e subjetivo do mundo (o conhecimento sobre a natureza física, as relações humanas, as identidades, as crenças, valores e mitos etc.) em relatos. A partir dos enunciados narrativos, somos capazes de colocar as coisas em relação umas com as outras em uma ordem e perspectiva, em um desenrolar lógico e cronológico. É assim que compreendemos a maioria das coisas do mundo (Motta, 2005, p. 2). 
O fenômeno da convergência midiática, fruto da evolução tecnológica aplicada à comunicação e à informação traz mudanças significativas nos meios de comunicação e nas formas como nos relacionamos com eles. O conceito transmídia ou transmidiático emerge desse ambiente, uma vez que as narrativas transitam de um meio a outro, de uma plataforma a outra, complementam-se e têm o seu conteúdo expandido pela ação interativa do receptor como produtor de conteúdos.

As narrativas midiáticas, as que mais consumimos no nosso cotidiano são também frutos da relação de muitas vozes, que nem sempre, contudo, resultam em um texto polifônico, ou seja, os filtros da mediação determinam uma linha de pensamento que apaga muitas vozes ou tira delas o seu peso de influência. Portanto, nem sempre produzir conteúdo a partir da recepção significa participação de fato. Embora a tecnologia propicie uma verdadeira sinfonia das vozes presentes, o que se encontra em grande parte é a superficialidade das relações e uma ditadura da onipresença, com a obrigatoriedade de se fazer presente em todos os ambientes.

O desafio midiático não é efetuar o trânsito entre as múltiplas possibilidades de suportes e formatos, o que não é novo em termos de comunicação, mas sim a expansão do conteúdo na medida em que esse trânsito acontece:

\begin{abstract}
A narrativa transmídia é considerada o resultado da articulação das distintas partes de uma grande narrativa, todas elas complementares e ligadas a esta. Cada uma está veiculada pela plataforma que melhor potencialize suas características expressivas. Por fazer parte da contemporaneidade na era das redes colaborativas, as comunicações entre os meios, entre os meios e os espectadores e entre os espectadores fortalecem as articulações da narrativa transmídia, como um movimento intensamente criativo e socializador (Renó, Versuti, Gonçalves e Gosciola, 2011, s/p).
\end{abstract}

Dessa forma, a mensagem, atrelada a várias mídias, vai se expandindo e fica impregnada das peculiaridades de cada uma delas, o que dá origem a um mosaico comunicacional chamado de croundsourcing ou sociedade colaborativa. A internet tem sido o palco dessa atuação e envolvimento dos conhecimentos coletivos e voluntários na criação de projetos inovadores. 
Vivenciamos uma ditadura da participação e da inclusão, que não deixa a opção de apenas receber passivamente, ainda que estejamos no contexto do entretenimento. A propaganda, o jornalismo, o cinema, as organizações, os diversos coletivos de mídia exigem a participação do público, pois a mensagem fica inacabada sem essa interferência ou atuação. A opção de não participar provoca exclusão, a menos que o sujeito tenha em mente não fazer parte do seu tempo e da sua sociedade.

\section{Uma outra ecologia comunicacional}

Expoentes na área da comunicação já se dedicaram em lançar luzes sobre o advento das mídias de massa, da evolução dos aparatos tecnológicos até os dispositivos móveis, da internet, da convergência tecnológica, da multimidialidade, da interatividade, constituintes de uma nova ecologia comunicacional ou Media Ecology (Postman, 2000), sociedade midiatizada (Fausto Neto, 2008), ou ainda bios midiático (Sodré, 2002). Nesse cenário de muitas transformações na velocidade da luz, da volatilidade e da liquidez (Bauman, 2001), são apenas alguns dos aspectos que marcam a modernidade tardia ou a pós-modernidade.

Nesse contexto, o "sujeito é descentrado" (Hall, 2000, p. 13), e a mídia e a comunicação passam cada vez mais a ter centralidade no cotidiano. Essa centralidade, como diz Sodré (2002), diz respeito a uma nova forma de viver, a uma "ambiência". O autor descreve a mídia como o "quarto bios": "Eu desenvolvo a minha visão comunicacional como uma nova esfera de domesticação, de colocar o homem em um novo tipo de casa”. Essa casa tem utensílios, suas disposições, seus "envoltórios técnicos", "uma esfera sobre a outra" (Rabelo, 2001, s/p).

A metáfora que exemplifica a abstração de Sodré sobre a sociedade contemporânea como bios midiático é, por outro lado, analisada por Santaella (2008, p. 95) como sobreposição/mescla/hibridização das culturas oral, escrita, impressa, de massa, das mídias e da cibercultura. A cada nova mídia, ocorrem rearranjos dessas culturas e uma "refuncionalização" de cada uma delas, considera a autora. Dessa forma, há uma convivência (nem tão harmônica), uma sobreposição, uma interdependência, que forma uma “ecologia midiática híbrida”, conceito que nos remete à ideia de sistema. 


\begin{abstract}
Embora misturada às outras, cada formação cultural funciona socialmente de maneiras diversas. A cultura dos meios de massa, do jornal à televisão, opera socialmente de modo muito diverso da cultura das mídias e de maneira ainda mais distinta do modo como opera a cibercultura. Quando isso é levado em consideração, evitam-se os equívocos correntes que nascem da imposição sobre uma formação cultural de critérios de julgamento e crítica que são empregados para uma formação cultural distinta (Santaella, 2008, p. 95).
\end{abstract}

Um dos aspectos marcantes dessa nova ecologia é a diferença entre os meios tradicionais e digitais, como diz Rubleski (2013, p. 187), "Digitalização e convergência que propiciam uma significativa diferença entre os meios tradicionais e a ecologia midiática atual: a interatividade”.

Nessa nova ecologia, o modelo produtor-receptor que marcou a cultura de massas e os meios tradicionais, como TV, rádio e jornais, é colocado em xeque. As tecnologias digitais viabilizam cada vez mais a participação/ colaboração do velho receptor, o que provoca desequilíbrios na ordem hierárquica anteriormente estabelecida. $\mathrm{O}$ receptor se torna produtor de conteúdo nas mídias digitais (em blogs, sites, redes sociais), que afetam/ modificam as relações de poder e, assim, mudam conteúdos e a sua reverberação social. Nesse jogo entre conteúdo e circulação da informação, há um "deslocamento da ênfase na produção para o da circulação" (Dias, 2014, p. 2), já que no ciberespaço atuam "interagentes” (Primo, Cassol, 1999, p. 77), gatekeepers e gatewatchers (Canavilhas, 2015), em interdependência com as mídias tradicionais. Assim, diz Rubleski (2013) ao citar Fidalgo, a informação produzida pelos meios se realiza na sociedade.

Mesmo com os algoritmos que direcionam conteúdos, a criação de bancos de dados para ações de marketing, o monitoramento do internauta, o loteamento do ciberespaço pelas gigantes de comunicação -o que desmonta, até certo ponto, a utopia da simetria comunicacional entre mídia e cidadão-, não há como negar que a apropriação das tecnologias digitais e da internet pela sociedade se constitui em uma brecha importante para se pensar a nova ecologia midiática.

Renó (2013) discute a nova configuração apresentando a evolução dos meios e da cultura, mencionando a interatividade, intertextualidade, 
mobilidade, potencializadas pela web 2.0, como elementos importantes na sociedade contemporânea. $\mathrm{O}$ autor vai além e destaca a geração multimídia, ou a sociedade multimídia, que se organiza a partir do uso de diversas mídias simultaneamente. As instituições sociais tradicionais são deixadas de lado, os sujeitos agem por meio de coletivos de mídia ${ }^{4}$, em comunidades as mais distintas, em busca da resolução de necessidades, como visibilidade, identidade social, compartilhamento de boas práticas e sucessos, sobrevivência para gerar renda e fazer negócios, entre outras. Há uma certa naturalidade (talvez naturalização) no uso da tecnologia no cotidiano, porém, ressalta Renó, isso não denota a caracterização de uma sociedade tecnocêntrica:

\begin{abstract}
[...] una sociedad que, aun que viva inmersa en la tecnología y sus ventajas, no es tecno céntrica. Ellos viven la tecnología naturalmente. Ellos nacieran en el mundo binario, y no sienten sus características participaren de su vida. Los trazos son binarios y hacen parte de su vida. Son seres intertextuales. Conviven con distintos "textos" al mismo tiempo, con una naturalidad que no existe para los que pertenecen a otras generaciones. Por esto la búsqueda constante de producir contenidos intertextuales en los medios de comunicación hoy en día (Renó, 2013, p. 23).
\end{abstract}

São os nativos digitais ou, conforme cita Renó (2011, s/p), os groundswell, que usam as ferramentas tecnológicas para diversas atividades, para relacionamento, para resolver problemas com empresas, para alcançar metas pessoais. Porém, é preciso ressaltar que a geração multimídia que produz seu próprio conteúdo também consome informação e entretenimento de outras fontes, nas mídias digitais e tradicionais. Em razão disso, TVs, rádios, jornais e revistas reagem para angariar e garantir audiências/ leitores, para sobreviver na ecologia midiática do século XXI. Cada vez mais, especialmente nos meios eletrônicos, há ofertas de espaços de interatividade, de conteúdos colaborativos, o que muda também a relação das novas gerações com as mídias tradicionais e vice-versa. Mudam também as estratégias/rotinas produtivas, além das narrativas, temas que têm estimulado diversos debates acadêmicos. É o que Santaella (2008) anali-

4 Grupos independentes e alternativos à grande mídia, a exemplo do Mídia Ninja, coletivo que ficou conhecido durante as manifestações de junho de 2013 no Brasil. Mais informações disponíveis em https://www.ufmg.br/online/ arquivos/028944.shtml (acesso em 20 ago. 2015). 
sa: uma nova cultura não elimina a outra, mas sim leva à hibridização de meios, produção e distribuição de conteúdos.

\section{Curtir, compartilhar e comentar: níveis de interatividade?}

A avalanche de conteúdos (os mais diversos possíveis) e a ubiquidade da tecnologia na vida cotidiana também podem acabar embotando a capacidade de agir no mundo. Uma certa angústia pela sobrecarga: 24 horas por dia conectados teclando mensagens, atualizando perfis nas redes sociais, expondo momentos de privacidade. E, se não estiver conectado, a sensação é de perda, de ânsia pela informação.

Interagir o tempo inteiro chega a ser desumano, mas no bios midiático é preciso se comunicar. Curtir, compartilhar e comentar têm sido um desafio na comunicação on-line. Mas nem sempre os níveis de interatividade consolidam uma situação comunicativa, um diálogo entre "interagentes" (Primo e Cassol, 1999, p. 77).

A interatividade caracteriza a comunicação on-line e tem sido abordada como elemento principal nas diferentes atividades e relacionamentos. As ferramentas disponíveis na internet podem ser um grande diferencial na produção/circulação de conteúdos para os diferentes segmentos da sociedade, do entretenimento aos negócios, das relações pessoais às profissionais.

Nos sites jornalísticos, por exemplo, as reportagens estáticas ganham dinamismo com enquetes, com a participação direta do leitor (que também ganha o status de produtor), além de jogos e infográficos multimídia relacionados com o tema abordado. Nos negócios, o possível consumidor é chamado a participar da divulgação da marca e do produto, muitas vezes, na própria elaboração e divulgação da mensagem publicitária. Porém, há que se considerar que nem sempre a relação homem/máquina garante uma comunicação interativa, de fato, do usuário com o conteúdo, originando uma troca e uma influência mútua. Muitas vezes, temos a falsa sensação de estarmos no comando quando, na verdade, só estamos seguindo os passos programados com antecedência. 
A interatividade tem sido um dos temas mais caros para se pensar o processo comunicacional na nova ecologia midiática. Há inúmeros conceitos a respeito do termo, depende de sua apropriação nos diversos campos de conhecimento, conforme expõem Jensen (1998) e Primo e Cassol (1999). Segundo o primeiro autor, interatividade "é o potencial de um meio em oferecer espaço ao usuário para que este influencie o conteúdo ou a forma da comunicação mediada” (Jensen, 1998, p. 201, tradução nossa). Já Primo e Cassol (1999, p. 77) consideram que a interatividade está no universo das mediações, nas "relações recíprocas que ocorrem entre as pessoas mediadas pelo computador".

Importante destacar que os autores das duas obras diferenciam os níveis de interatividade. $\mathrm{O}$ primeiro destaca quatro tipos: interatividade de transmissão, de consulta, de conversação e de registro. São gradações que abrangem a interatividade entre cidadão e máquina, cidadão e mídia e entre cidadãos (comunidades, coletivos).

Primo e Cassol, por seu lado, identificam dois tipos de interatividade: a reativa e a mútua. A primeira refere-se a um processo linear, mais mecanicista; a outra é dialógica e negociada (Primo e Cassol, 1999, p. 76). Os autores consideram que os dois tipos de interatividade podem ocorrer simultaneamente e, nesse sentido, o termo multi-interação, de Lemos e Mielniczuc (citado por Paiva, 2013), ajuda também a entender que a interatividade possui mais ou menos limitações, depende do potencial tecnológico, que inclui acesso e diversidade, e da estratégia comunicativa de empresas, veículos de comunicação e cidadãos. De acordo com essa relação, o cidadão pode ser interagente (Primo e Cassol, 1999), ator (Recuero, 2009) ou prossumidor (Toffler, 2014).

Portanto, quando se pensa em interatividade, deve-se considerar o nível de interferência possível nos conteúdos definidos, ou melhor, deve-se ter em mente não apenas a produção de conteúdos ou a reação a eles, mas o que o usuário pode fazer com eles. Trata-se de uma nova concepção de conteúdo e de consumo cultural "mais orientado à ação do que à contemplação e, por isso mesmo, mais integrado na vida social dos usuários. 
Assim, os aplicativos são o sintoma de um profundo processo de transformação do conteúdo" (Aguado e Güere, 2013, p. 57). Para os autores, a lógica da comunicação, sobretudo a partir do aperfeiçoamento dos dispositivos móveis, aponta para a fusão entre conteúdo e aplicação, na direção de ampliar os horizontes do fazer e da circulação. Curtir, comentar, produzir e compartilhar.

\section{O sujeito como estratégia de sobrevivência}

Nesse contexto, as interações por meio de ações e/ou reações resultam em novas práticas comunicacionais e novos formatos midiáticos, encontrados tanto no jornalismo quanto na publicidade, mas também nos textos das organizações em geral em contato com seus variados públicos.

No que se refere ao jornalismo, alguns autores estabelecem diferenças entre jornalismo colaborativo e participativo, porém, nem todos os investigadores da área fazem essa distinção. No primeiro caso, o receptor envia conteúdos "por meio de textos, fotos e vídeos, distribuídos pela rede”, que são inseridos e viabilizados por meio de "plataforma centralizada informativa e dependente de seus princípios estabelecidos. Os termos de usos descritos nos websites possuem diferentes formatos, sendo caracterizados por organizações centralizadas ou descentralizadas” (Sbarai, 2010, p. 2).

As plataformas colaborativas na web oferecem, em princípio, acesso a todos, porém "desde que possuam competências necessárias para contribuir para uma produção considerada relevante ao formato pré-estabelecido no ambiente virtual” (Sbarai, 2010, p. 2). Já o jornalismo participativo é mais limitado, "tem um princípio apenas de auxiliar, participar, pressupõe compartilhar, ter parte em ou dividir algo que foi produzido e idealizado por apenas uma pessoa" (Sbarai, 2010, p. 1).

A colaboração ou participação em conteúdos jornalísticos depende do modelo jornalístico adotado, como já foi dito, e isso está relacionado com o propósito do veículo e dos produtores/receptores. Pode ser um coletivo de imprensa, como o Mídia Ninja (Narrativas Independentes, Jornalismo e Ação), que atua nas redes sociais em sites como Twitter e Facebook; uma ONG, como a Agência Pública de Jornalismo Investigativo, organização 
não governamental que realiza reportagens investigativas por meio de crodfunding e crowdsourcing; uma empresa de comunicação de conteúdo geral e/ou especializado, com público-alvo local, nacional ou global. Podem estar nas redes sociais ou em plataformas, como portais, sites e blogs, associados a uma cadeia de outros veículos de comunicação, como o impresso, televisivo e radiofônico. Um exemplo no Brasil é o Globo.com, portal da Rede Globo, que reúne todas as plataformas, ou o Portal R7, ligado à Rede Record de Televisão (que não possui título impresso de prestígio, diferentemente da Rede Globo).

Em todos os modelos há interatividade em maior ou menor grau, mútua ou reativa, ou ainda "pseudomútua" (Primo e Cassol, 1999), com a indispensável associação às redes sociais, especialmente Facebook e Twitter, além do uso de aplicativos, como Whatsapp (ou aplicativos exclusivos criados por empresas jornalísticas). Podemos dizer que há, em alguns espaços noticiosos, até certa dependência da participação do receptor-produtor. Porém, não propriamente por causa da qualidade do conteúdo gerado pelo cidadão, mas porque é uma maneira de conquistar a audiência, de atrair a sua atenção, de valorizar sua contribuição como forma de fidelizá-la.

O consumidor atual, ao participar das redes sociais digitais, passa a atuar de forma efetiva nas relações de compra e venda: ele comenta sobre os produtos, positiva e negativamente, cria e publica vídeos, compartilha ideias, influencia e é influenciado. "Quando compradores e vendedores trocam mais informações, o preço se torna fluido” (Tapscott, 2010, p. 257). Dessa forma, a instituição e a marca estão constantemente na berlinda e cada dia mais têm sua imagem e reputação colocadas à prova. Portanto, monitorar essas ações e reações nas redes sociais digitais faz parte do compromisso das organizações preocupadas com sua integridade, honestidade, confiabilidade, consideração e transparência e, ainda que em última instância, com o lucro. A comunicação convencional não dá conta de atender às demandas desse novo cenário.

Consciente da postura desse novo consumidor, as empresas têm se inserido no mundo digital e investido no conceito de coparticipação. Em 
artigo recente (Gonçalves e Souza, 2015), analisamos o caso da Fiat que, no ano de 2010, lançou o Novo Uno, fruto de um intenso diálogo entre os designers do Centro Estilo Fiat para América Latina, o Centro Estilo Fiat da Itália e os consumidores. Nessa mesma linha de participação, a marca lançou um vídeo em 2014, centrado na cantora de músicas pop Anita e seus dançarinos. Foi criado um primeiro vídeo em que a cantora convidava os internautas a participarem da gravação da propaganda da marca e divulgou-se nas redes sociais. No vídeo, a cantora ensinava os passos da dança e, ao final, um link remetia o interessado em participar para um blog da marca, com toda estrutura virtual para a gravação do filme. Alguns vídeos foram selecionados e utilizados na gravação da propaganda. O primeiro vídeo, com o apelo da cantora para a participação, ocorreu em outubro de 2014 e obteve $115 \mathrm{mil}$

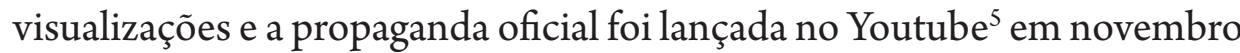
de 2014 e um mês depois apresentou 3,5 milhões de visualizações.

Este é apenas um dos exemplos nos quais o consumidor atua a partir de um incentivo da empresa e aceita o desafio de montar seu próprio vídeo e poder fazer parte do mundo da publicidade, do mundo digital e agregar para si o sucesso da marca e da empresa (as visualizações do vídeo da Fiat passavam a fazer parte das visualizações do seu perfil individual). Evidentemente, a marca ganha o público com um investimento publicitário reduzido e um retorno de confiabilidade e parceria que pode ser muito grande.

Portanto, no âmbito da comunicação nas organizações, a ênfase discursiva recai sobre o humano e sobre as emoções, e substitui o foco do compromisso entre níveis hierárquicos diferentes e da oferta de conteúdos para suprir necessidades, relações que comandaram a sociedade de produtores O compromisso social das empresas, midiáticas ou não, e a preocupação com a qualidade de vida são elementos argumentativos, hoje, para o consumo. Antes, a tarefa era oferecer produtos/serviços/conteúdos para suprir as necessidades e atender à demanda do público, agora são os valores humanizantes que estão no centro dessa relação, nessa sociedade de consumidores (Bauman, 2008).

5 Propaganda oficial com a participação dos consumidores: https://www.youtube.com/watch?v=hEVU1EPJwSA 
Os novos valores fazem emergir um discurso essencialmente participativo e as relações de consumo passam a interessar pesquisadores que identificam tais mudanças. Daniel Galindo (2013) apresenta o consumidor contemporâneo em sua dimensão mais humanizada ou social de re(ação), sujeito que transita em meio a fluxos multidirecionais de comunicação e compartilha de forma autônoma, espontânea, dialógica e contributiva suas impressões sobre as marcas e imagens corporativas, e rejeita, portanto, uma comunicação de caráter invasiva e não dialógica ao agir independentemente das intenções ou manobras das organizações.

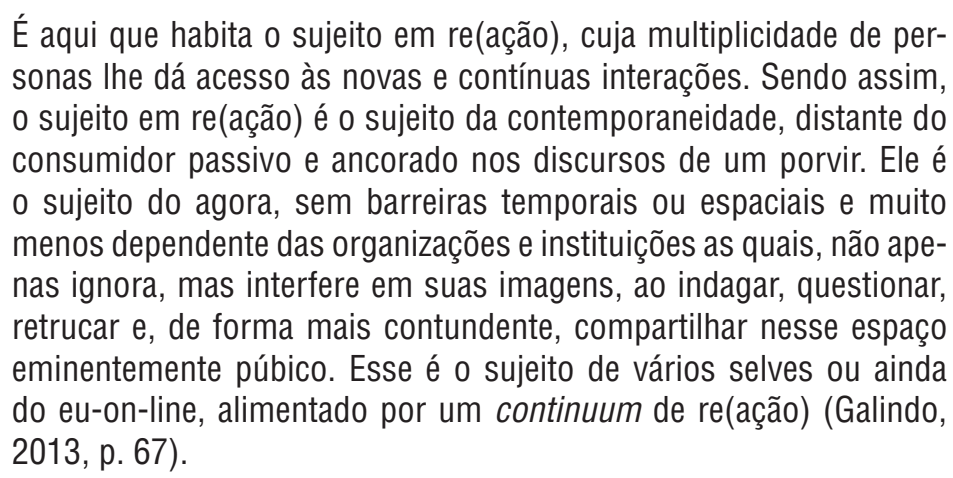

Vivemos, portanto, a valorização da audiência, do consumidor, a partir de argumentos que enfatizam a participação e o poder de escolha, ainda que, em última instância, o que se busca é a sedução e a persuasão do cidadão.

\section{Novas formas de contar história}

A evolução da internet, sobretudo com as redes sociais digitais, tem propiciado oportunidades de todos contarem suas histórias, com objetivos os mais diversos, desde uma proposta séria, curricular em redes profissionais até o encantamento do trivial, as brincadeiras entre amigos, os relacionamentos amorosos. As empresas não demoraram a encontrar esse espaço para contar sua própria história, de divulgar seus produtos, serviços e marcas.

O que se conta, evidentemente, é um recorte intencional, com vistas a atingir determinados objetivos. $O$ perfil pode ser totalmente falso, mas pode dar origem a um relacionamento esperado. Portanto, não importa o que se conta, mas como se conta a história. Ao perceber o poder sedutor 
das narrativas, a publicidade não vende mais produtos ou serviços: vende emoção por meio de histórias narradas; os produtos têm sua própria história, que nem sempre é verdadeira. Cabe lembrar casos emblemáticos do suco Do bem e sorvete Diletto, questionadas no Conselho Nacional de Autorregulamentação Publicitária (Conar) devido à falsidade de suas histórias. Os sucos Do bem alegavam que a laranja utilizada em seu suco integral provinha de uma fazenda de propriedade do Sr. Francisco (personagem criada), quando na verdade quem fornece o suco para a Do Bem são empresas como a Brasil Citrus, que vende o mesmo produto para outras marcas. Já a paulistana Dilleto, fabricante de sorvetes categorizados como gourmet, foi denunciada por contar uma história falsa sobre o possível proprietário da marca e também sobre a composição do sorvete - haveria uma mistura de "neve" às frutas!

As ações no Conar e o impedimento de circulação das histórias infundadas denotam que o público está preocupado com a veracidade das informações e tem capacidade de julgar. Portanto, não aceita, mesmo na publicidade, gênero no qual a criatividade pode lançar mãos de recursos ficcionais, que a história contada não seja condizente com a realidade; sente-se enganado, pois é uma ficção que se mostra como realidade, diferentemente do contexto totalmente irreal, no qual personagens e objetos fictícios são plenamente aceitáveis e até premiados.

Ainda como estratégias de aproximar o público, as organizações, em suas estratégias de comunicação usam o storytelling (termo em inglês para a contação de histórias) para a construção de sua imagem. As histórias de vida dos grandes líderes das corporações passam a fazer parte dela. Claro que se trata de uma história editada, em que só o sucesso da luta é evidenciado. Na mesma linha de contar histórias, a empresa busca relatar em seus boletins e jornais as histórias de seus empregados, agora promovidos ao status de colaboradores. Estes, ao se verem retratados pela empresa, sentem-se parte dela. Dessa forma, a valorização da empresa pelo destaque às pessoas que a fazem funciona de forma positiva para a imagem de humanização das relações, ainda que muitas vezes não passe de discurso retórico e a prática da gestão mostre um outro lado conservador e com vistas ao lucro imediato. 
O entretenimento saiu na frente na busca de explorar a narrativa transmídia como forma de inserir o outro na história e torná-lo parceiro na autoria dos conteúdos. Jenkins (2008) cita vários exemplos bem-sucedidos dessa nova forma de compor uma história. Os casos do filme A bruxa de Blair (The Blair Witch Project) ${ }^{6}$, um dos pioneiros na experiência transmídia, e os de sucesso arrebatador, como em Matrix e os da saga Harry Potter, como Harry Potter e a pedra filosofal (Harry Potter and the Philosopher's Stone ${ }^{7}$ são referências para os estudiosos. No conjunto de ofertas de conteúdo que se complementaram em várias plataformas, o receptor é chamado a participar do set de filmagens, a jogar o game, a ler o livro, o que reverbera também os conteúdos nas redes sociais.

O jornalismo vive essa experiência de buscar formatos novos para vencer a luta contra o imediatismo da informação rápida e da sobrecarga de conteúdos. Os exemplos estão presentes no telejornalismo, radiojornalismo, no jornalismo impresso e no jornalismo on-line. A revista Superinteressante oferece reportagens multimídia, em interatividade reativa, como dizem Primo e Cassol (1999), como na reportagem A batalha de Belo Monte ${ }^{8}$. Há os infográficos interativos, como o que mostra o Mapa do emprego ${ }^{9}$, produzido pelo jornal Folha de S. Paulo, uma nova forma de narrar as histórias e que apresenta também em linguagem multimídia diversos conteúdos, os quais podem ser acessados de diversas formas pelo internauta.

Um dos exemplos de maior interatividade na mídia brasileira é o Portal R7, terceiro no ranking de portais, segundo pesquisa da Secretaria da Comunicação da Presidência da República —Secom- (Martins, 2014). Conforme entrevista realizada por Viegas, um dos jornalistas que atuam na redação do Portal, a produção noticiosa depende intensamente da participação da audiência, que fica conectada ao veículo. Há sugestões de pautas, indicação de fontes e de personagens, envio de fotos, imagens, entre ou-

6 Curiosidades sobre o filme em disponíveis em http://medob.blogspot.com.br/2013/03/curiosidades-sobre-o-filme-bruxa-de.html (acesso em 20 ago. 2015).

7 Informações disponíveis em http://www.filmesonlinegratis.net/assistir-harry-potter-e-a-pedra-filosofal-dublado -online.html (acesso em 20 ago. 2015).

8 Disponível em http://arte.folha.uol.com.br/especiais/2013/12/16/belo-monte/ (acesso em 20 ago. 2015).

9 Disponível em http://www1.folha.uol.com.br/infograficos/2013/05/18441-mapa-do-emprego.shtml (acesso em 20 ago. 2015). 
tros; entretanto, as colaborações passam pelo controle do jornalista, que pode ou não agregá-las à produção jornalística do Portal.

Em um outro estudo realizado por Moraes, Temer e Coelho (2013), as autoras avaliaram a contribuição da audiência nos conteúdos da afiliada da Rede Globo de Televisão, TV Anhanguera. No entanto, as autoras concluíram que a participação da população é pouco valorizada e não há, inclusive, orientação aos jornalistas de como deveriam ser selecionados os conteúdos participativos, "a não ser a necessidade de promover maior interação com os receptores” (p. 146).

\section{Algumas considerações}

A ecologia midiática na contemporaneidade propicia novas dinâmicas nas práticas comunicacionais em diversas plataformas e em diversos formatos. Essa realidade coloca a interatividade como elemento primordial nas relações entre produtor e receptor, que se tornam sujeitos produtores e receptores ao mesmo tempo. Mídia e cidadão são autores e coautores dos conteúdos disponibilizados nas mídias, os quais são reverberados em dimensões expoenciais nas redes sociais, e também nos meios tradicionais, como TV, rádio, jornais e revistas.

O sujeito e a humanização dos conteúdos passam a ser elementos recorrentes no discurso e nos conteúdos das mídias, porém nem sempre os sujeitos em (re)ação configuram uma situação de efetiva comunicação. Não se deve deixar de ressaltar que as novas tecnologias tenham propiciado uma nova relação com o receptor, anteriormente limitado pelo modelo comunicacional da mídia massiva.

No novo cenário, há um embaralhamento das fronteiras de produção e recepção e um desafio à classificação estanque dos produtos midiáticos, e de seus conteúdos, como simplesmente informativos ou de entretenimento, propagandísticos ou persuasivos — ou tudo junto e misturado.

Como já dissemos, há uma valorização da audiência, do consumidor, a partir de argumentos que enfatizam a participação e o poder de escolha. 
A nova ecologia midiática representa, assim, um novo habitar das relações entre produtor-receptor, presididas pelo consumo, cuja aura de envolvimento facilita esse relacionamento.

\section{Referências}

Aguado, J. M. e Güere, H. N. (2013). Comunicación móvil, ecosistema digital e industrias culturales. En Aguado, J. M., Feijóo, C. e Martínez, I. J. (Orgs.), La Comunicación Móvil - Hacia un nuevo ecosistema digital. Barcelona: Gedisa Editorial.

Bauman, Z. (2001). Modernidade líquida. Rio de Janeiro: Jorge Zahar Ed.

Bauman, Z. (2008). Vida para consumo: A transformação das pessoas em mercadorias. Rio de Janeiro: Zahar.

Canavilhas, J. (2015) Do gatekeeping ao gatewatcher: o papel das redes sociais no ecossistema mediático. II Congreso Internacional Comunicación 3.0, Universidade de Salamanca, Espanha. Recuperado em 15 ago. 2015 de <http://campus.usal.es/ comunicacion3punto0/ comunicaciones/061.pdf>

Dias, M. S. M. (2014). O jornalismo em vias de midiatização: o contrato de leitura e suas negociações em Zero Hora. SBPJor — Associação Brasileira de Pesquisadores em Jornalismo $12^{\circ}$ Encontro Nacional de Pesquisadores em Jornalismo, Santa Cruz do Sul (Unisc). Recuperado em 15 ago. 2015 de soac.unb.br/index.php/ENPJor/ XIIENPJor/paper/download/3676/713.

Fausto Neto, A. (2008). Fragmentos de uma "analítica" da midiatização. Matrizes, 1(2). Recuperado em 15 ago. 2015 de http:/ /www.matrizes.us:br/index.php/matrizes/article/view/88.

Galindo, D. S. (2013). O sujeito social em sua persona de consumidor em re(ação). Em Gonçalves, E. M. (Org.), Práticas Comunicacionais: 
sujeitos em (re)ação (pp. 51-67). São Bernardo do Campo: Editora Metodista.

Gonçalves, E. M. e Souza, V. (2015). Discursos organizacionais: as relações de consumo no ambiente das redes sociais digitais. Revista Organicom, 12(22).

Hall, S. (2000). A identidade cultural na pós-modernidade. $4^{\mathrm{a}}$ ed. Rio de Janeiro: DP\&A.

Jenkins, H. (2008). Cultura da convergência. Tradução de Susana Alexandria. São Paulo: Aleph.

Jensen, J. F. (1998). Interactivity: Tracking a new concept in media and communication studies. Recuperado em 31 ago. 2015 de http://www. nordicom.gu.se/en/tidskrifter/nordicom-review-11998/interactivity-tracking-new-concept-media-and-communication-studies

Martins, L. C. (2014). Secom/Ibope divulgam raio-x da mídia brasileira. Recuperado em 30 ago. 2015 de http://www.ocafezinho.com/2014/03/07/ secom-ibope-divulgam-raio-x-da-midia-brasileira $>$.

Moraes, A., Temer, A. C. R. e Coelho, B. (2013). Participação popular e os valores-notícia no telejornalismo. Brazilian Journalism Research, 9(2). Recuperado em 15 ago. 2015 de http://bjr.sbpjor.org.br/ bjr/article/viewFile/541/496.

Motta, L.G. (2005). A Análise Pragmática da Narrativa Jornalística. Recuperado em $1^{\circ}$ ago. 2015 de http://www.portcom.intercom.org. $\mathrm{br} / \mathrm{pdfs} / 105768052842738740828590501726523142462 . \mathrm{pdf}>$.

Paiva, A. P. (2013). A interatividade no jornalismo online para o conteúdo das notícias - O perfil interativo dos jornais de língua portuguesa: Folha de S. Paulo (Brasil) e Público (Portugal). $2^{a}$ Conferência de Língua Portuguesa. Recuperado em 15 ago. 2015 de http://webcache. 
googleusercontent.com/search?q=cache:G2OPF4VXqEkJ:www. conferencialp.org/files/ariane_interatividade_jornalismo2. $\mathrm{pdf}+\& \mathrm{~cd}=1 \& \mathrm{hl}=\mathrm{pt}-\mathrm{BR} \& \mathrm{ct}=\mathrm{clnk} \& \mathrm{gl}=\mathrm{br}$.

Postman, N. (2000). The Humanism of Media Ecology. Media Ecology Association. Recuperado em 15 ago. 2015 de http://www.mediaecology.org.

Primo, A. F. T. e Cassol, M. B. F. (1999). Explorando o conceito de interatividade: conceitos e taxonomias. Informática na educação: teoriaß prática, 2(2). Recuperado em 15 ago. 2015 de http://seer.ufrgs.br/index.php/InfEducTeoriaPratica/article/ view/6286/3756.

Rabelo, D. (2001). Objeto da comunicação é a vinculação social. Entrevista. PCLA, 3(1). Recuperado em 15 ago. 2015 de http://www2. metodista.br/unesco/PCLA/revista9/entrevista\%209-1.htm.

Recuero, R. (2009). Redes Sociais na Internet, Difusão de Informação e Jornalismo: elementos para discussão. Recuperado em $1^{\circ}$ ago. 2015 de http://www.raquelrecuero.com/artigos.html.

Renó, D. P. (2013). Discussões sobre a nova ecologia dos meios. CAC - Cuadernos Artesanos de Comunicación, 39. Recuperado em $1^{\circ}$ ago. 2015 de https://www.academia.edu/9779434/Discuss\%C3\%B5es sobre_a_nova_ecologia_dos_meios.

Renó, D., Versuti, A., Gonçalves, E. e Gosciola, V. (2011). Narrativas transmídia: diversidade social, discursiva e comunicacional. Revista Palabra Clave, 14(2). Recuperado em $1^{\circ}$ ago. 2015 de http:// palabraclave.unisabana.edu.co/index.php/palabraclave/article/ view/1973/2531.

Rubleski, A., Barichelo, E. (2013). Ecologia da Mídia. Santa Maria, RS: Editora Facos. 
Santaella, L. (2008). Mídias locativas: a internet móvel de lugares e coisas. Famecos, 35. Recuperado em $1^{\circ}$ ago. 2015 de http://www.revistas. univerciencia.org/index.php/famecos/article/viewArticle/5371.

Sbarai, R. (2010). Motivações do cidadão-repórter na produção jornalística em ambientes virtuais: incentivo, recompensa e reconhecimento. Comtempo, 2(1). Recuperado em 10 jul. 2015 de http:// www.revistas.univerciencia.org/index.php/comtempo/article/ viewFile/6915/6482.

Sodré, M. (2002). Antropológica do Espelho - uma teoria da comunicação linear e em rede. Petrópolis, RJ: Vozes.

Tapscott, D. (2010). A hora da geração digital: como os jovens que cresceram usando a internet estão mudando tudo, das empresas aos governos. Rio de Janeiro: Agir Negócios.

Toffler, A. (2014). A terceira onda. Tradução: João Távora. 32a edição. Rio de Janeiro: Record.

Wolf, M. (1999). Teorias da Comunicação. Lisboa: Presença. 